\title{
How to foster the formation of STEM identity: studying diversity in an authentic learning environment
}

\author{
Alison Singer ${ }^{1 *}$ (D), Georgina Montgomery ${ }^{2,3}$ and Shannon Schmoll ${ }^{4}$
}

\begin{abstract}
Background: STEM identity has been shown to have a powerful role in an individual's success in educational environments, as well as on their career goals and trajectories. Historically, however, STEM identity formation for underrepresented students has been hampered by the lack of representation of in STEM fields, which predominantly consist of white males. One educational challenge is diversifying STEM classrooms, both in terms of the students themselves and also in terms of the science and scientists they learn about.

Methods: We piloted a 4-credit History, Philosophy, and Sociology of Science course at Michigan State University. Students were tasked with creating exhibits focused on themes of diversity and inclusion in science for a real client. Using a STEM identity survey, we assessed students' attitudes towards the sciences, issues of diversity in science, and their sense of belonging to their educational communities. We also had the students respond to various shortanswer questions throughout the semester to better understand their experiences working on a collaborative authentic learning task.
\end{abstract}

Results: Our results suggest that authentic learning experiences based around ideas of diversity and inclusion can help students develop sense of belonging and positive STEM identities. Students demonstrated shifts in their selfidentities as scientists, focusing more on the intersection between their gender, ethnicity, and self-perception as a scientist. Through qualitative analysis of short-answer questions, we were able to ascertain that working in groups in an authentic learning environment helped the students improve their communication and collaboration skills.

Conclusions: Students' increased focus on gender and ethnicity suggests that they are thinking critically about how their personal identities intersect with their scientific identities. Additional research would help us better understand if the coupling of authentic learning and inclusive teaching practices have significant impacts on the formation of students' STEM identities.

Keywords: Authentic learning, STEM identity, Sense of belonging, Diversity

\section{Introduction}

STEM (science, technology, engineering, and mathematics) identity has been defined as the way people make "the concept of fitting in within STEM fields, specifically, the way individuals make 'meaning of science experiences and how society structures possible meanings"

\footnotetext{
* Correspondence: alison.singer@nau.edu

1 Department of Biological Sciences, Northern Arizona University, 617 S.

Beaver St., Flagstaff, AZ 86001, USA

Full list of author information is available at the end of the article
}

(Carlone and Johnson 2007, Hughes et al. 2013). People who have developed STEM identities can be described as those who "think about themselves as science learners and develop an identity as someone who knows about, uses, and sometimes contributes to science" (Center for the Advancement of Informal Science Education 2018). STEM identity has been shown to have a powerful role in an individual's success in educational environments, as well as on their career goals and trajectories (Chemers et al. 2011, Perez et al. 2014, Simpson and Bouhafa

\section{Springer Open}

(c) The Author(s). 2020 Open Access This article is licensed under a Creative Commons Attribution 4.0 International License, which permits use, sharing, adaptation, distribution and reproduction in any medium or format, as long as you give appropriate credit to the original author(s) and the source, provide a link to the Creative Commons licence, and indicate if changes were made. The images or other third party material in this article are included in the article's Creative Commons licence, unless indicated otherwise in a credit line to the material. If material is not included in the article's Creative Commons licence and your intended use is not permitted by statutory regulation or exceeds the permitted use, you will need to obtain permission directly from the copyright holder. To view a copy of this licence, visit http://creativecommons.org/licenses/by/4.0/. 
2020). Historically, however, STEM identity formation for underrepresented students has been hampered by the lack of representation of in STEM fields, which predominantly consist of white males (Alegria and Branch 2015, Bernard and Cooperdock 2018). One educational challenge is diversifying STEM classrooms, both in terms of the students themselves and also in terms of the science and scientists they learn about.

Active learning is one strategy that has been shown to increase exam performance in STEM undergraduate students (Freeman et al. 2014) and may also contribute to the development of more positive STEM identities and increased retention in STEM majors (Beier et al. 2019). Authentic learning, a form of active learning in which students focus on real-world issues over a long period of time, is a specific approach that may improve both student retention and performance (Beier et al. 2019, Torres et al. 2016). Beier et al. (2019) demonstrated that authentic learning experiences were correlated with higher levels of STEM career aspirations, higher levels of self-efficacy in STEM skills, and higher ratings of the usefulness of STEM courses in undergraduate education. However, these results were similar across demographics, suggesting that authentic learning experiences are not sufficient to increase underrepresented students' STEM identities to similar levels as their white male colleagues' (Beier et al. 2019).

Because of the importance of STEM identity formation, particularly for traditionally underrepresented students, including women and ethnic and racial minorities, we designed an undergraduate course to encourage and foster STEM identities through a semester-long authentic learning project and through teaching about diversity and inclusion in the space program. The course was a 100 level History, Philosophy, and Sociology of Science course taught in an undergraduate residential college focused on science and society at Michigan State University. The primary motivation behind the development of the course was a desire to create an inclusive learning environment, both within the classroom-in terms of the course content, assignments, and pedagogy - and beyond the classroom by helping to create public spaces on campus focused on diversity in STEM. A secondary motivation was to weave content knowledge focused on historical and contemporary issues of diversity and inclusion in STEM with transferable skills such as the ability to effectively work in teams and to generate products in an authentic environment. As such, the course was designed to be both deeply relevant (to their major, to their career goals, etc.) and deeply meaningful (to their sense of identity and sense of belonging) for each student enrolled in the class.

In this article, we first provide a brief overview of STEM identity and the strands of STEM identity that we determined to be particularly important. We then discuss the course design itself, followed by our assessment methods, the results, and our conclusions and ideas for future research. This case study demonstrates that authentic learning experiences based around ideas of diversity and inclusion can help students develop sense of belonging and positive STEM identities, and in particular, STEM identities that are rooted in ethnic and gender identities. Furthermore, we suggest that combining teaching about diversity and inclusion with an authentic learning approach may foster critical self-reflection about issues of gender and race as they relate to an individual's perception of who is a scientist and their own relationship with science, though more research needs to be done in this area

\section{STEM identity}

To better foster learning and living environments that help students develop positive STEM identities, it is important to understand how these identities are developed and nurtured through institutions of formal education. We have identified three important contributors to STEM identity formation: (1) teaching for diversity and inclusion through exposure to role models (Johnson 2012); (2) an individual's sense of belonging to an educational institution and to the STEM field(s) (Maton et al. 2016, Rainey et al. 2018); and (3) authentic learning experiences (Beier et al. 2019, Wallace and Bodzin 2017, Chi et al. 2015). These different strands are not mutually exclusive, and in particular, diversity and inclusion is deeply tied to sense of belonging, particularly for individuals who may not see their own identities reflected in the dominant STEM depictions or in educational institutions.

For example, Gumpertz, Durodoye, Griffith, and Wilson (2017) show that tenure-track faculty in STEM disciplines are far more likely to be white and male than an ethnic or racial minority, or a female. This imbalance means that undergraduate students are generally exposed to the dominant white male professor in the course of their STEM education, limiting their exposure to role models who may look like themselves. The experiences of black undergraduate students suggest that being surrounded by primarily white students and instructors contributed to a feeling of social and intellectual isolation, which in turn makes it more difficult for them to find study partners and other students to collaborate with (McClain 2014).

To best foster positive STEM identities at the undergraduate level, we argue that it requires a focus on both diversity and sense of belonging, which can be facilitated through authentic learning experiences. Below, we briefly explore the literature related to each of these strands of STEM identity.

\section{Diversity and inclusion}

Research suggests that incorporating diversity and inclusion in college courses and campus activities can help 
students develop sense of belonging, confidence, engagement, and academic achievement (see e.g., Laird 2005, Zuniga et al. 2005, Puritty et al. 2017). Laird (2005) found that undergraduate students who interacted with diverse peers and took classes that emphasized diversity are more likely to demonstrate self-confidence, critical thinking skills, and agency. Puritty et al. (2017) argue that underrepresented students in STEM programs need to "embrace their identities," and that institutions and STEM culture must create ways to foster this.

Emphasizing diversity and inclusion in teaching specifically targets students' exposure to role models in STEM fields that are more inclusive and reflective of a diverse student population. Research has shown that access to role models-educators, professionals, parents, etc.-that individuals can relate to can increase the development of a positive STEM identity (Hughes et al. 2013, Ramsey et al. 2013). Specifically, Ramsey et al. (2013) found that exposure to in-group role models (i.e., role models of the same gender, race, or ethnicity as an individual) can increase motivation and persistence in STEM fields and lead to stronger STEM identities in undergraduate females.

STEM educational environments often foster a sense of belonging for white males, while tacitly marginalizing people of color and women (Johnson 2012, Ramsey et al. 2013, Tonso 1999). This privilege of white maleness extends beyond STEM education; Johnson et al. (2007) demonstrate that students of color often have less of a sense of belonging to their campus community than do white students. Studies show that experiences of racial discrimination and bias negatively affect students' sense of belonging, as well as student retention (Hurtado and Alvarado 2015).

However, even in the face of institutionalized white male privilege, teaching for diversity and inclusion can help nurture a STEM identity and a sense of belonging, particularly for underrepresented minorities. Embracing multicultural content in STEM classrooms contributes to a "legacy of competence" by representing the historical contributions of students' cultural ancestors (Hinnant-Crawford 2016). For example, to counter institutionalized biases, the "stereotype inoculation model" suggests that women can develop stronger implicit STEM identities through exposure to positive cues in their surroundings. Studies have shown that US (United States) female college students who were exposed to ingroup (female) role models and experts demonstrated stronger implicit STEM identities, and in turn increased motivation and persistence in STEM fields. Their perceptions of male-STEM stereotypes stayed the same in these cases (Dasgupta 2011, Stout et al. 2011).

\section{Sense of belonging}

A sense of belonging to a community of peers is important to both developing a STEM identity and retention in
STEM education programs (Johnson 2012). Strayhorn (2012) defines a sense of belonging as "students' perceived social support on campus, a feeling or sensation of connectedness, and the experience of mattering or feeling cased about, accepted, respected, valued by, and important to the ... community" (pg. 4). Sense of belonging is scaffolded within a university environment, as students can feel at home in, for example, their dormitories, their university, their chosen field of study, and other various communities. As students make the transition from high school to college, there are several opportunities to develop a sense of belonging to various groups and organizations on campus. However, research shows that it is more difficult for underrepresented students, including women and students of color, to develop a sense of belonging within a university setting (Ramsey et al. 2013). These challenges may be exacerbated in the STEM fields, which are dominated by white males (Hughes et al. 2013, Rainey et al. 2018).

Research shows that underrepresented minorities and first-generation college students are particularly vulnerable to dropping out of higher education programs, and that the lack of a sense of community contributes to this vulnerability (O'Keefe 2013). In STEM programs in particular, underrepresented minorities describe stigmas associated with being an underrepresented individual in science (Hurtado et al. 2010). McClain (2014) showed that race can play a significant role in students' education experiences, resulting in less positive identities as mathematicians. Similarly, Rainey et al. (2018) found that undergraduate white men in STEM disciplines reported a higher sense of belonging than any other demographic, and that women of color reported the lowest sense of belonging. However, there are strategies to increase an individual's sense of belonging to an educational community or the STEM fields, particularly for students who do not identify as white males. For example, Walton and Cohen (2011) introduced an intervention design to assuage fears about long-term social isolation in college, which resulted in improved senses of well-being and higher grades, particularly for AfricanAmerican students. In addition, participating in research has been correlated with long-term interest in STEM for underrepresented students (Hernandez et al. 2013).

\section{Authentic learning experiences}

Authentic learning experiences are those developed to align better with the way learning is achieved in realworld environments (Herrington et al. 2014). Herrington and Oliver (2000) suggest that authentic learning experiences should be designed around characteristics that focus on real-world relevance over a long period of time (Bransford et al. 1990, Reeves and Reeves 1997); the exposure to and collaborating with multiple roles and 
perspectives; reflection; articulation of knowledge and learning, particularly through public presentation (Edelson 1996); scaffolding; and authentic assessment. These experiences focus on solving real-world problems through role-playing, participation in virtual or face-to-face communities of practice, and case studies. Authentic learning intentionally introduces multiple perspectives and interdisciplinarity (Lombardi 2007).

Both students and instructors exhibit preferences for learning-by-doing as opposed to learning-by-listening, though implementing authentic learning in a classroom can prove challenging (Lombardi 2007). In theory, authentic learning can help students better judge the reliability of information, develop and follow longer arguments, identify patterns, and become more flexible and dynamic collaborators across disciplines and cultural boundaries (Lombardi 2007). Studies of undergraduate students show that authentic learning experiences may contribute to increased empathy (Donnelly et al. 2019), increased understanding of the theoretical underpinnings of a field (Smith et al. 2015), and the development of stronger STEM identities (Anthony et al. 2017, Martin-Hansen 2018, Mraz-Craig et al. 2018). Authentic learning experiences may also contribute to increased engagement and self-efficacy measures, particularly for underrepresented students (Chemers et al. 2011).

\section{Course overview}

This case study took place in a 100 level, 4-credit course called Introduction to History, Philosophy, and Sociology of Science at Michigan State University. The students enrolled in the course were freshmen who were part of a residential learning college (Lyman Briggs College) with a focus on science. This specific section of the course had an emphasis on authentic learning and diversity, as explained below. We used a different section of the same course, without the focus on authentic learning and diversity, as a control class.

The treatment course created an authentic learning experience by creating a semester-long collaboration between the students and a client, who in this case was the Director of the Abrams Planetarium. The course was designed with the goal of being focused on skill development and student-led research experiences that mirror real life, with a particular emphasis on diversity in science and in the space program in particular. The client shared her request-the kinds of products desired for public display-and logistical and budget limitations for the production of the final products. After hearing the client's request, students worked in learning teams of 45 students to develop their initial ideas and then pitched their proposal to the client using the format of a flash presentation. At this time, initial feedback was given by the client, the professor, and by peers in the class regarding what would work well and areas for improvement or revision. Additional feedback was also given regarding feasibility, budgeting concerns, and ways the proposed project could integrate into other aspects of the planetarium's displays and youth programming.

Students continued to develop their ideas and projects and met with the client at least twice more at the planetarium itself and communicated regularly with the client over email. Students were responsible for contacting the client and arranging a meeting for the whole team. The first visit was shortly after the original pitch to discuss further changes after initial feedback. Students were also able to ask questions and ask for more specific feedback as well. A second meeting was a few weeks later with the intent of showing initial versions of content and to work through any additional issues, though most teams had yet to build or prototype any additional content at this time.

By the end of the semester, each team had physically built or produced their final product and presented their exhibit to the professor and the client. It was clear the students did incorporate many suggestions. The final products were then given in either digital or physical form to the client to incorporate into the planetarium's public displays and/or for future youth programming.

Running alongside planning, researching, and building their group final projects, students read about the contributions of women and other underrepresented groups to space research and astronomy. Activities included reading primary sources featured in the Smithsonian Museum's digital collection, watching the movie Hidden Figures, reading the book Almost Heaven, and conducting a phone interview with Nancy Grace Roman. Periodically, students were prompted to reflect on their learning and the impact of the class content and assignments on their views of themselves as scholars and scientists. For example, there was an in-class identity chart activity and an in-class reflection activity about how the students identified as a future STEM professional. Overall, these activities introduced students to underrepresented scientists and STEM professionals, and also encouraged them to reflect upon their own identities as students, scholars, and scientists.

\section{Student demographics}

Both the treatment and the control classes were comprised of majority female and majority white students. The treatment class was more ethnically diverse, with approximately $40 \%$ of the students identifying as non-white, compared with approximately $25 \%$ of the students in the control class identifying as non-white. Both classes had between 55 and $60 \%$ of the students identify as female.

\section{Methods}

To assess how students' identities developed and changed throughout the semester, we created a STEM identity 
survey (see Appendix 1) that addresses sense of belonging (to Lyman Briggs, Michigan State University, and STEM fields), exposure to diversity, and a student's sense of identification as a scientist and as a scholar. Our survey was compiled from surveys that have already been tested and validated in the literature, and we adapted questions to make them specific to the residential college and the University. We specifically adapted survey and interview instruments from Hughes et al. (2013), Ramsey et al. (2013), and Bollen and Hoyle (1990).

We administered the survey both during the first 2 weeks of the semester and during the final 2 weeks of the semester to assess change. We administered the survey to the treatment classroom as well as to a control classroom that did not include an authentic learning component or a particular emphasis on diversity and inclusion. This allowed us to compare the differences in change in student STEM identities between the classrooms. The control classroom had 23 students, and the treatment classroom had 24 students. Note that in the beginning of the semester there were a few students in each class that were not yet 18 years of age, and therefore did not take the survey. We performed independent sample $t$ tests on the pre-surveys to see if there were any initial significant differences between the classes. To analyze change over time by classroom, we performed paired sample $t$ tests on the STEM identity surveys in both the treatment and control classrooms.

In the treatment classroom, the students also responded to short-answer questions twice during the semester, once near the beginning of their exhibit creation and once near the end (see Appendix 2). They answered questions regarding their expectations about the project, their personal contributions, the challenges of collaboration, and their client interactions. To analyze these responses, we used an emergent coding process, modeled on Humble (2009). This process allowed common themes to emerge from the student's responses, which we then categorized into broader categories. Based on student responses, we were able to group specific questions together, as the student responses were largely similar. We also developed broad themes for each question group and more specific sub-themes. We then compared the frequencies of each category to assess what students were consistently writing about in their responses.

\section{Results}

Comparisons between the control and treatment classes for the initial survey revealed few significant differences (nine out of the 58 questions). In general, these differences reflected that students in the control classroom had more faith in science and saw more evidence of diversity in science in their daily lives than did the students in the treatment classroom.
Results of the pre- and post-STEM identity surveys are shown in Tables 1 and 2 . We included only the statements that saw significant change over the semester. We used a significance threshold of $p<0.1$ to account for the fact that this is exploratory research, and we are interested in trends to look for in future research.

In our qualitative analysis of the open-ended questions students answered twice during the semester, we identified two primary emergent themes that the students focused on: personal development as a student and collaboration skills. In addition, we identified sub-themes that we grouped into these two main categories. Table 3 shows the number of students who spoke positively about each of the sub-themes and the main themes. Because the majority of responses were similar across both times that the questions were asked, for this analysis, we used only the responses given during the final part of the project.

Finally, we coded the challenges that the students encountered in their authentic learning projects, developing emergent categories. Table 4 shows the frequency of the categorized challenges that were mentioned by the students.

\section{Discussion}

\section{STEM identity survey}

Our results suggest that authentic learning experiences, when combined with teaching about diversity and inclusion, may positively influence students' STEM identities and prepare them for future coursework and professional experiences. The survey results highlight the differences between the control classroom and the treatment classroom. In the control classroom, the significant changes in student responses primarily dealt with traditional markers of academic education, though the change was not necessarily in the expected direction. Students did report feeling more confident about their math abilities, but they were less concerned with learning new topics. Students in the control class also reported an increased sense of belonging with the scientific community and were more likely to identify as a scientist.

In the treatment classroom, students exhibited more change overall. Like the control group, they too were more likely to identify as a scientist; unlike the control group, however, they also intertwined their gender and ethnic identities with their scientific identity, as exhibited through increased agreement with the following statements: "My gender identity is an important part of my being a scientist," and "My ethnic identity is an important part of my being a scientist." Previous research has suggested that active learning environments may help foster positive STEM identities regardless of student demographics (Freeman et al. 2014, Beier et al. 2019, Torres et al. 2016); however, because underrepresented students often have more negative STEM 
Table 1 Mean agreement with the survey statement for the control group

\begin{tabular}{|c|c|c|c|c|}
\hline Statement & Pre-survey mean (SD) & Post-survey mean (SD) & Direction change & $P$ value \\
\hline I am confident in my ability to succeed in my university math courses. & $4.00(1.00)$ & $4.47(0.72)$ & Increase & 0.09 \\
\hline I have a strong sense of belonging to the scientific community. & $3.53(0.72)$ & $3.88(0.70)$ & Increase & 0.06 \\
\hline I have come to think of myself as a scientist. & $3.18(1.07)$ & $3.88(0.78)$ & Increase & 0.02 \\
\hline It is important to me that I learn a lot of new concepts this year. & $4.76(0.56)$ & $4.47(0.72)$ & Decrease & 0.10 \\
\hline One of my goals in class is to learn as much as I can. & $4.71(0.59)$ & $4.06(0.83)$ & Decrease & 0.00 \\
\hline My chances of succeeding later in life depend on doing well in college. & $4.29(1.05)$ & $4.71(0.77)$ & Increase & 0.07 \\
\hline
\end{tabular}

Students responded on a Likert scale of $1-5$, with 1 being strongly disagree and 5 being strongly agree

identities (including concepts of self-efficacy and sense of belonging) (Beier et al. 2019, Chemers et al. 2011), there is a recognized need to develop strategies to provide learning environments that particularly focus on these students. Our treatment classroom, which coupled an authentic learning project with increased exposure to diversity in STEM, was an attempt to do this. While our sample size was too small to statistically determine if underrepresented students saw greater increases in their STEM identities than did other students, the overall increases in the importance of their genders and ethnicities to their self-identities as scientists suggests that this approach may have been successful.

Additionally, the treatment group showed significant change in their perceptions of exposure to underrepresented groups in STEM, including women and people of color. We can hypothesize that the students felt more exposure to underrepresented groups because of the focus of the course. In the future, it would be useful to ask if they also began noticing underrepresented scientists more outside of the course; it may be that their exposure made them more capable of noticing underrepresented scientists than they were before taking this course. Alternatively, they may simply have been exposed to these scientists within this course but nowhere else in their lives.

Compared to the control classroom, the students in the treatment group showed an increased sense of belonging to the residential college community. Research shows that group collaboration in learning environments may help foster a sense of community (Manning and Saddlemire 1996, Salazar et al. 2012), so working closely with members of the residential college community throughout the course of a semester may have helped students feel more integrated into that particular community. Additionally, creating positive peer interactions may be particularly useful for underrepresented students, contributing to them developing sense of belonging (Johnson et al. 2007). Fostering an inclusive, collaborative atmosphere in this course may have contributed to the increase in sense of belonging to Lyman Briggs exhibited by the students.

Table 2 Mean agreement with the survey statement for the treatment group

\begin{tabular}{|c|c|c|c|c|}
\hline Statement & $\begin{array}{l}\text { Pre-survey mean } \\
\text { (SD) }\end{array}$ & $\begin{array}{l}\text { Post-survey mean } \\
\text { (SD) }\end{array}$ & $\begin{array}{l}\text { Direction } \\
\text { change }\end{array}$ & $P$ value \\
\hline Being a scientist is an important part of my self-image. & $3.17(0.92)$ & $3.78(1.11)$ & Increase & 0.02 \\
\hline $\begin{array}{l}\text { I often see images of high-achieving woman scientists in museums or other } \\
\text { public spaces. }\end{array}$ & $2.72(0.90)$ & $3.28(0.96)$ & Increase & 0.02 \\
\hline Today's complex problems require interdisciplinary solutions. & $3.82(0.73)$ & $4.41(0.80)$ & Increase & 0.00 \\
\hline Today's complex problems require scientists to work effectively in teams. & $4.06(0.90)$ & $4.59(0.71)$ & Increase & 0.02 \\
\hline I often hear or read about high-achieving female scientists. & $2.82(0.95)$ & $3.44(1.03)$ & Increase & 0.06 \\
\hline I have come to think of myself as a scientist. & $2.88(1.05)$ & $3.41(1.00)$ & Increase & 0.05 \\
\hline My ethnic identity is an important part of my being a scientist. & $2.24(0.90)$ & $2.82(0.95)$ & Increase & 0.10 \\
\hline My gender identity is an important part of my being a scientist. & $2.59(1.42)$ & $3.41(1.28)$ & Increase & 0.04 \\
\hline $\begin{array}{l}\text { I often see images of high-achieving scientists of color in museums or other } \\
\text { public spaces. }\end{array}$ & $2.47(0.94)$ & $3.12(0.49)$ & Increase & 0.02 \\
\hline I often see images of or read about high-achieving woman scientists in textbooks. & $2.47(1.07)$ & $3.12(1.05)$ & Increase & 0.03 \\
\hline $\begin{array}{l}\text { Often, the people in the Lyman Briggs community trust me with things that are important } \\
\text { to them. }\end{array}$ & $3.06(0.83)$ & $3.47(0.72)$ & Increase & 0.09 \\
\hline I am a scientist. & $3.06(1.20)$ & $3.71(1.21)$ & Increase & 0.08 \\
\hline People of the Lyman Briggs community count on me to be there in times of need. & $2.76(0.90)$ & $3.35(1.00)$ & Increase & 0.01 \\
\hline My chances of succeeding later in life depend on doing well in college. & $4.29(0.92)$ & $3.65(1.17)$ & Decrease & 0.04 \\
\hline
\end{tabular}

Students responded on a Likert scale of 1-5, with 1 being strongly disagree and 5 being strongly agree 
Table 3 Short-answer questions that the students answered throughout the semester

\begin{tabular}{|c|c|c|c|}
\hline \multirow{2}{*}{\multicolumn{3}{|c|}{$\begin{array}{l}\text { Collaboration skills developed } \\
\text { What did you get out of and contribute to this project? }\end{array}$}} & \\
\hline & & & \multirow[b]{2}{*}{9} \\
\hline Teamwork and communication & 17 & Research skills & \\
\hline Time management & 9 & Writing skills & 6 \\
\hline Personal relationships & 3 & Project-specific learning and work & 18 \\
\hline Encouragement and enthusiasm & 4 & & \\
\hline Accountability to a group & 5 & & \\
\hline \multicolumn{4}{|c|}{$\begin{array}{l}\text { How did this class prepare you for future college courses and contribute to your } \\
\text { goals as a Lyman Briggs student? }\end{array}$} \\
\hline Teamwork and communication & 24 & Research skills & 3 \\
\hline \multirow[t]{2}{*}{ Community-building } & 4 & Writing skills & 7 \\
\hline & & General personal development & 14 \\
\hline
\end{tabular}

This table shows the number of students who discussed the specific themes in their responses

The students in the treatment course also showed increased agreement that today's complex problems require interdisciplinary team science to solve. The authentic learning experience was designed to mimic real-world experiences; research shows that science is becoming more team-based and interdisciplinary (e.g., Bozeman and Bozeman 2014, Hazra et al. 2019). These students worked as part of a small group throughout the semester, which may contribute to the changes in how they view the necessity for interdisciplinary and team science. Salazar et al. (2012) suggest that when scientists work in interdisciplinary groups they build communication skills, a shared sense of belonging, and an understanding of how their individual knowledge and skills can contribute to addressing complex problems.

Finally, there were differences in how students changed their thinking about learning between the two groups. In the control group, students indicated greater confidence in their ability to succeed in math courses at the end of the semester, though this particular course did not deal with math in any way, so we have no hypothesis as to why this may have occurred. It is important to note that the $p$ value here is high, and so this result may not be significant, or it may be that students felt more confident overall, and this is reflected in their response. In the control group as well, students were less invested in learning new things in general. Despite their decrease in interest in

Table 4 List of challenges that students described in their responses

\begin{tabular}{lc}
\hline What were the biggest challenges you had to overcome? \\
\hline Teamwork and communication & 10 \\
Scheduling & 9 \\
Accountability and reliability & 6 \\
Giving up control & 5
\end{tabular}

This table shows the number of students who commented on the specific challenges they had to overcome learning new things, the students in the control group showed an increased belief that their chances of succeeding in life are dependent upon how well they do in school, though again the significance is marginal.

In the treatment group, however, the only significant change regarding learning explicitly was a decrease in the belief that their chances of success in life depend upon how well they do in school. This was an unexpected and interesting result, and we posit that it may be due to their exposure to underrepresented scientists. In general, these scientists had to overcome discrimination, biases, and sometimes outright harassment to succeed, despite their ambition, hard work, and intellect. We hypothesize that through learning about these institutionalized barriers to success, the students may have developed a richer understanding of how success is shaped by external as well as internal desires and forces (e.g., McIntosh 1988, Ong et al. 2018), and therefore became less inclined to believe that hard work and good grades will allow them to achieve their goals. This is something that has not been well-studied, and we suggest that further research would be useful here.

It is important to address the initial differences between the two classes, though our primary goal with this research was to measure changes over the semester. The treatment class was more ethnically diverse than the control class, which may account for the fact that they initially felt less exposed to scientists of color-their own ethnicities may have made them more aware of the absence of scientists of color, while the less diverse class may have assumed a more diverse representation despite a lack of evidence. Similarly, the less diverse population may have exhibited more faith in science because of their exposure to scientists who reflect their own identities. More research with larger sample sizes would be useful to address these questions about diversity and perceptions of diversity in science.

\section{Short-answer questions: collaboration and development}

Throughout all the questions, two primary themes emerged, dealing with (1) collaboration and (2) personal development as a student. In terms of collaboration, students focused on communication, dynamics of group work, and having accountability to a group. When they spoke of personal development as a student, they discussed either traditional educational learning outcomes such as research and writing skills or softer skills such as confidence.

As shown in Table 3, the students in general focused more on how they developed teamwork and collaboration skills as opposed to more traditional learning gains such as research and writing skills. One of the primary goals of the class was to foster communication and demonstrate how collaborative work and research creates both challenges and rewards, and so we consider it a 
success that so many students commented about how their communication and teamwork skills were improved. We also believe that because of the novelty of the course (i.e., a semester-long, group project for a client), students were more likely to emphasize the novel aspects of the work as opposed to the more expected learning gains in research and writing.

Similarly, many of the students mentioned that they developed skills useful for their specific project, but that may or may not be translatable to other courses or work. For example, one group created an exhibit that used the digistar, which is software specific to the planetarium. Students also often talked about how they had particular skills that contributed to these very specific aspects of their exhibit, such as coding, painting, or wood-cutting.

When asked about what skills they had developed, many students expressed that they had gained general skills that would help them succeed as a student in the future, such as confidence in their work or the ability to ask an instructor for help. While some of these responses were specific, many of them simply noted that they felt like they were better students or better prepared for the future, so we are unable to interpret those any more specifically, which is why we created the "general personal development" category to encompass these "soft skills" along with the general statements. In the future it would be useful to ask for more specific responses to the open-ended questions. Alternatively, based on the responses from this study, we could develop a list of specific skills that we expect students to develop, and frame the questions as yes/ no or on a Likert scale. This would increase our ability to generalize and compare results, but we would lose some of the richness of the open-ended responses.

\section{Short-answer questions: challenges}

As seen in Table 4, the primary challenges the students faced in this authentic learning experience were related to collaboration and communication. Ten students noted that teamwork and communication were the most challenging aspects of the work; this category included things like being open-minded about everyone's different ideas and the general difficulties of interpersonal communication in a group. Scheduling was a common problem, as the students all had different schedules and different extra-curricular activities. Students also highlighted the difficulties of working with people who procrastinated or missed classes or scheduled meetings (accountability and reliability).

On a more personal level, several students mentioned that it was difficult for them to give up control in the group setting. For example, one student noted that "as an individual, it is hard for me to trust in a group to do everything on time," and another said that "I had to overcome taking control because I like knowing that I was able to get a specific thing done."
As this course was taught primarily to freshmen, it is likely that this was their first large-scale group project in which they had to consistently work with a group over the course of a semester. One of the goals of authentic learning was to introduce students to collaborative knowledge construction (Herrington et al. 2014), and the challenges cited by student suggest that we were successful in this. Moreover, while collaboration proved difficult for the students, they largely appeared to overcome the challenges of teamwork and communication, as evidenced by their short-answer responses (see Table 3).

\section{Conclusions}

We developed and taught a 4-credit History, Philosophy, and Sociology of Science course in a residential college at Michigan State University in fall of 2018. The course was specifically designed to introduce ideas of diversity and inclusion in STEM, through various activities and texts, as well as a semester-long authentic learning experience. To assess the success of this course, we developed a STEM identity survey and asked a series of short-answer questions throughout the semester. We administered the STEM identity survey to a control classroom that did not have a focus on diversity and inclusion or an authentic learning project.

Our results suggest that the focus on diversity and the authentic learning project helped contribute to the development of stronger STEM identities when compared to the control class. Students in the treatment class consistently showed more change in their STEM identities, with particular increases around their identities as not only scientists, but scientists for whom their genders and ethnicities are an important part of who they are. While our sample size was too small to evaluate if underrepresented students experienced more or less change in their STEM identities, the increased focus on gender and ethnicity suggests that students are at the very least, thinking critically about how their personal identities intersect with their scientific identities. Additional research would help us better understand if the coupling of authentic learning and inclusive teaching practices have significant impacts on the formation of students' STEM identities.

Through qualitative analysis of short-answer questions given to the students in the treatment class, we were able to ascertain that working in groups in an authentic learning environment helped the students improve their communication and collaboration skills. While the course work presented challenges to the students, they were largely able to overcome them through teamwork. The students also improved their research and writing skills, and learned some specific skills such as particular technologies and software. 


\section{Appendix 1}

Table 5 STEM identity survey

\begin{tabular}{|c|c|c|c|c|c|c|}
\hline & Question & $\begin{array}{l}\text { Strongly } \\
\text { disagree }\end{array}$ & $\begin{array}{l}\text { Somewhat } \\
\text { disagree }\end{array}$ & Neutral & $\begin{array}{l}\text { Somewhat } \\
\text { agree }\end{array}$ & $\begin{array}{l}\text { Strongly } \\
\text { agree }\end{array}$ \\
\hline 1 & Being a scientist is an important part of my self-image. & 1 & 2 & 3 & 4 & 5 \\
\hline 2 & $\begin{array}{l}\text { Having more people with my background in my field makes me feel more like } \\
\text { a scientist. }\end{array}$ & 1 & 2 & 3 & 4 & 5 \\
\hline 3 & $\begin{array}{l}\text { I have noticed that sometimes the people in the Lyman Briggs community will } \\
\text { inconvenience themselves to help me. }\end{array}$ & 1 & 2 & 3 & 4 & 5 \\
\hline 4 & My ethnic identity is an important part of who I am. & 1 & 2 & 3 & 4 & 5 \\
\hline 5 & I enjoy studying with other students in a group. & 1 & 2 & 3 & 4 & 5 \\
\hline 6 & I often hear or read about high-achieving scientists of color. & 1 & 2 & 3 & 4 & 5 \\
\hline 7 & I am a Briggsy. & 1 & 2 & 3 & 4 & 5 \\
\hline 8 & $\begin{array}{l}\text { I often see images of or read about high-achieving scientists of color in } \\
\text { textbooks. }\end{array}$ & 1 & 2 & 3 & 4 & 5 \\
\hline 9 & Group projects are valuable. & 1 & 2 & 3 & 4 & 5 \\
\hline 10 & $\begin{array}{l}\text { Thinking of myself as a scientist is compatible with other aspects of my } \\
\text { background. }\end{array}$ & 1 & 2 & 3 & 4 & 5 \\
\hline 11 & Other students in class take my suggestions/comments seriously. & 1 & 2 & 3 & 4 & 5 \\
\hline 12 & I am confident in my ability to succeed in my university humanities courses. & 1 & 2 & 3 & 4 & 5 \\
\hline 13 & $\begin{array}{l}\text { I can effectively be a member of a team to design and build a hands-on } \\
\text { project. }\end{array}$ & 1 & 2 & 3 & 4 & 5 \\
\hline 14 & I look forward to my science courses. & 1 & 2 & 3 & 4 & 5 \\
\hline 15 & I am a Spartan. & 1 & 2 & 3 & 4 & 5 \\
\hline 16 & I look forward to my math courses. & 1 & 2 & 3 & 4 & 5 \\
\hline 17 & $\begin{array}{l}\text { I often see images of high-achieving woman scientists in museums or other } \\
\text { public spaces. }\end{array}$ & 1 & 2 & 3 & 4 & 5 \\
\hline 18 & I intend to complete a degree in science. & 1 & 2 & 3 & 4 & 5 \\
\hline 19 & I am confident in my ability to succeed in my university math courses. & 1 & 2 & 3 & 4 & 5 \\
\hline 20 & I have a strong sense of belonging to the scientific community. & 1 & 2 & 3 & 4 & 5 \\
\hline 21 & It is my choice to study science. & 1 & 2 & 3 & 4 & 5 \\
\hline 22 & $\begin{array}{l}\text { The science courses in Lyman Briggs will prepare me for a job in a scientific } \\
\text { field. }\end{array}$ & 1 & 2 & 3 & 4 & 5 \\
\hline 23 & The HPS courses in Lyman Briggs will prepare me for a job in a scientific field. & 1 & 2 & 3 & 4 & 5 \\
\hline 24 & Today's complex problems require interdisciplinary solutions. & 1 & 2 & 3 & 4 & 5 \\
\hline 25 & Today's complex problems require scientists to work effectively in teams. & 1 & 2 & 3 & 4 & 5 \\
\hline 26 & I like my current living situation. & 1 & 2 & 3 & 4 & 5 \\
\hline 27 & I know where I can find the information I need to solve a difficult problem. & 1 & 2 & 3 & 4 & 5 \\
\hline 28 & More time should be spent on hands-on projects in college. & 1 & 2 & 3 & 4 & 5 \\
\hline 29 & $\begin{array}{l}\text { I can explain science to my friends to help them understand a problem or an } \\
\text { issue. }\end{array}$ & 1 & 2 & 3 & 4 & 5 \\
\hline 30 & $\begin{array}{l}\text { There are people at Lyman Briggs who care enough about me to criticize me } \\
\text { when I need it. }\end{array}$ & 1 & 2 & 3 & 4 & 5 \\
\hline 31 & I often hear or read about high-achieving female scientists. & 1 & 2 & 3 & 4 & 5 \\
\hline 32 & I look forward to my humanities courses. & 1 & 2 & 3 & 4 & 5 \\
\hline 33 & I have come to think of myself as a scientist. & 1 & 2 & 3 & 4 & 5 \\
\hline 34 & My ethnic identity is an important part of my being a scientist. & 1 & 2 & 3 & 4 & 5 \\
\hline 35 & I am confident in my ability to succeed in my university science courses. & 1 & 2 & 3 & 4 & 5 \\
\hline 36 & Society values the work that scientists do. & 1 & 2 & 3 & 4 & 5 \\
\hline 37 & Scientists help to make the world a better place. & 1 & 2 & 3 & 4 & 5 \\
\hline
\end{tabular}


Table 5 STEM identity survey (Continued)

\begin{tabular}{|c|c|c|c|c|c|c|}
\hline & Question & $\begin{array}{l}\text { Strongly } \\
\text { disagree }\end{array}$ & $\begin{array}{l}\text { Somewhat } \\
\text { disagree }\end{array}$ & Neutral & $\begin{array}{l}\text { Somewhat } \\
\text { agree }\end{array}$ & $\begin{array}{l}\text { Strongly } \\
\text { agree }\end{array}$ \\
\hline 38 & My gender identity is an important part of my being a scientist. & 1 & 2 & 3 & 4 & 5 \\
\hline 39 & It is important to me that I learn a lot of new concepts this year. & 1 & 2 & 3 & 4 & 5 \\
\hline 40 & I'm certain I can figure out how to do the most difficult course work. & 1 & 2 & 3 & 4 & 5 \\
\hline 41 & The people of the Lyman Briggs community tend to rely on me for support. & 1 & 2 & 3 & 4 & 5 \\
\hline 42 & One of my goals in class is to learn as much as I can. & 1 & 2 & 3 & 4 & 5 \\
\hline 43 & I prefer to do work as I have always done it, rather than trying something new. & 1 & 2 & 3 & 4 & 5 \\
\hline 44 & Doing well in school won't guarantee that I will get a good job later in life. & 1 & 2 & 3 & 4 & 5 \\
\hline 45 & Being a part of Lyman Briggs is important to me. & 1 & 2 & 3 & 4 & 5 \\
\hline 46 & $\begin{array}{l}\text { I often see images of high-achieving scientists of color in museums or other } \\
\text { public spaces. }\end{array}$ & 1 & 2 & 3 & 4 & 5 \\
\hline 47 & I can effectively lead a team to design and build a hands-on project. & 1 & 2 & 3 & 4 & 5 \\
\hline 48 & Being a scientist is an important reflection of who I am. & 1 & 2 & 3 & 4 & 5 \\
\hline 49 & $\begin{array}{l}\text { I often see images of or read about high-achieving woman scientists in } \\
\text { textbooks. }\end{array}$ & 1 & 2 & 3 & 4 & 5 \\
\hline 50 & Sometimes in Lyman Briggs I almost feel as if I am invisible. & 1 & 2 & 3 & 4 & 5 \\
\hline 51 & Sometimes at MSU I almost feel as if I am invisible. & 1 & 2 & 3 & 4 & 5 \\
\hline 52 & At Lyman Briggs social gatherings, no one recognizes me. & 1 & 2 & 3 & 4 & 5 \\
\hline 53 & I feel like I belong in the field of science. & 1 & 2 & 3 & 4 & 5 \\
\hline 54 & $\begin{array}{l}\text { Often, the people in the Lyman Briggs community trust me with things that } \\
\text { are important to them. }\end{array}$ & 1 & 2 & 3 & 4 & 5 \\
\hline 55 & I am a scientist. & 1 & 2 & 3 & 4 & 5 \\
\hline 56 & $\begin{array}{l}\text { People of the Lyman Briggs community count on me to be there in times of } \\
\text { need. }\end{array}$ & 1 & 2 & 3 & 4 & 5 \\
\hline 57 & My chances of succeeding later in life depend on doing well in college. & 1 & 2 & 3 & 4 & 5 \\
\hline 58 & People of the Lyman Briggs community tend to not remember my name. & 1 & 2 & 3 & 4 & 5 \\
\hline
\end{tabular}

\section{Appendix 2}

Pre-project interview questions

Q1. What do you hope to get out of this experience?

Q2. Please describe the challenges you foresee from working in a group.

Q3. What strengths that you have will help you contribute to this project?

Q4. How does this project contribute to your overall goals as a Lyman Briggs student?

Q5. Are you nervous about working for a client? Why or why not?

Post-project interview questions

Q6. What did you get out of this experience?

Q7. In what ways did you feel you best contributed to your group's success?

Q8. What were the biggest challenges you had to overcome?

Q9. How did this project contribute to your overall goals as a Lyman Briggs student?

Q10. As a result of this project, do you feel more prepared for your future college courses? Why or why not?
Q11. How were your expectations met or unmet throughout this project?

Q12. Has this project made you reconsider any of your academic or personal goals? Why or why not?

\section{Abbreviations}

STEM: Science, technology, engineering, and mathematics; US: United States

\section{Acknowledgements}

Not applicable

Authors' contributions

GM and SS developed the course. SS served as the client for the students.

AS and GM developed the measurement tools. AS conducted the data analysis. AS was the primary manuscript writer. All authors contributed to manuscript writing, and read and approved the final manuscript.

\section{Funding}

This work was supported by Lyman Briggs College at Michigan State University (MSU), the Scholarship of Undergraduate Teaching and Learning program at MSU, and the Abrams Planetarium at MSU.

Availability of data and materials

Datasets are available upon request from the corresponding author. 


\section{Competing interests}

The authors declare that they have no competing interests.

\section{Author details}

'Department of Biological Sciences, Northern Arizona University, 617 S. Beaver St., Flagstaff, AZ 86001, USA. 'Lyman Briggs College, Michigan State University, 919 E. Shaw Lane, East Lansing, MI 48825, USA. 'DDepartment of History, Michigan State University, 506 E. Circle Drive, East Lansing, MI 48825, USA. ${ }^{4}$ Abrams Planetarium, Michigan State University, 755 Science Road, East Lansing, MI 48824, USA.

\section{Received: 20 February 2020 Accepted: 4 October 2020}

Published online: 06 November 2020

\section{References}

Alegria, S. N., \& Branch, E. H. (2015). Causes and consequences of inequality in the STEM: Diversity and its discontents. International Journal of Gender, Science and Technology, 7(3), 321-342.

Anthony, A. K., Walters, L., \& McGrady, P. (2017). Creating connections between authentic research and the development of science identities in undergraduate Marine Biology experiences. Florida Scientist, 80(2/3), 61-76.

Beier, M. E., Kim, M. H., Saterbak, A., Leautaud, V., Bishnoi, S., \& Gilberto, J. M. (2019). The effect of authentic project-based learning on attitudes and career aspirations in STEM. Journal of Research in Science Teaching, 56(1), 3-23.

Bernard, R. E., \& Cooperdock, E. H. (2018). No progress on diversity in 40 years. Nature Geoscience, 11(5), 292.

Bollen, K. A., \& Hoyle, R. H. (1990). Perceived cohesion: A conceptual and empirical examination. Social Forces, 69(2), 479-504

Bozeman, B., \& Boardman, C. (2014). Research collaboration and team science: A state-of-the-art review and agenda. Springer.

Bransford, J. D. (1990). The cognitive and technology group at Vanderbilt. Anchored instruction and its relationship to situated cognition. Educat. Res, 19(5), 2-10.

Carlone, H. B., \& Johnson, A. (2007). Understanding the science experiences of successful women of color: Science identity as an analytic lens. Journal of Research in Science Teaching, 44(8), 1187-1218.

Center for the Advancement of Informal Science Education. (2018). Broadening participation task force: February 2018 update. Retrieved from http://www. informalscience.org/news-views/broadening-participation-task-forcefebruary-2018-update

Chemers, M. M., Zurbriggen, E. L., Syed, M., Goza, B. K., \& Bearman, S. (2011). The role of efficacy and identity in science career commitment among underrepresented minority students. Journal of Social Issues, 67(3), 469-491.

Chi, B., Dorph, R., \& Reisman, L. (2015). Evidence \& impact: Museum-managed STEM programs in out-of-school settings. National Research Council Committee on Out-of-School Time STEM. Washington, DC: National Research Council.

Dasgupta, N. (2011). Ingroup experts and peers as social vaccines who inoculate the self-concept: The stereotype inoculation model. Psychological Inquiry, 22(4), 231-246

Donnelly, S., Dean, S., Razavy, S., \& Levett-Jones, T. (2019). Measuring the impact of an interdisciplinary learning project on nursing, architecture and landscape design students' empathy. BioRxiv, 605097.

Edelson, D. C. (1996). Learning from cases and questions: The Socratic case-based teaching architecture. The Journal of the Learning Sciences, 5(4), 357-410.

Freeman, S., Eddy, S. L., McDonough, M., Smith, M. K., Okoroafor, N., Jordt, H., \& Wenderoth, M. P. (2014). Active learning increases student performance in science, engineering, and mathematics. Proceedings of the National Academy of Sciences, 111(23), 8410-8415.

Gumpertz, M., Durodoye, R., Griffith, E., \& Wilson, A. (2017). Retention and promotion of women and underrepresented minority faculty in science and engineering at four large land grant institutions. PloS One, 12(11), e0187285.

Hazra, R., Singh, M., Goyal, P., Adhikari, B., \& Mukherjee, A. (2019). The rise and rise of interdisciplinary research: Understanding the interaction dynamics of three major fields-Physics, Mathematics and Computer Science. In International Conference on Asian Digital Libraries (pp. 71-77). Cham: Springer.

Hernandez, P. R., Schultz, P., Estrada, M., Woodcock, A., \& Chance, R. C. (2013). Sustaining optimal motivation: A longitudinal analysis of interventions to broaden participation of underrepresented students in STEM. Journal of educational psychology, 105(1), 89.
Herrington, J., \& Oliver, R. (2000). An instructional design framework for authentic learning environments. Educational Technology Research and Development, 48(3), 23-48.

Herrington, J., Reeves, T. C., \& Oliver, R. (2014). Authentic learning environments. In Handbook of research on educational communications and technology, (pp. 401-412). New York, NY: Springer.

Hinnant-Crawford, B. N. (2016). Increasing access: The application of multicultural education to STEM. Journal for Multicultural Education, 10(3), 250-256.

Hughes, R. M., Nzekwe, B., \& Molyneaux, K. J. (2013). The single sex debate for girls in science: A comparison between two informal science programs on middle school students' STEM identity formation. Research in Science Education, 43(5), 1979-2007

Humble, Á. M. (2009). Technique triangulation for validation in directed content analysis. International Journal of Qualitative Methods, 8(3), 34-51.

Hurtado, S., Newman, C. B., Tran, M. C., \& Chang, M. J. (2010). Improving the rate of success for underrepresented racial minorities in STEM fields: Insights from a national project. New Directions for Institutional Research, 2010(148), 5-15.

Hurtado, S., \& Ruiz Alvarado, A. (2015). Discrimination and bias, underrepresentation, and sense of belonging on campus.

Johnson, D. R. (2012). Campus racial climate perceptions and overall sense of belonging among racially diverse women in STEM majors. Journal of College Student Development, 53(2), 336-346.

Johnson, D. R., Soldner, M., Leonard, J. B., Alvarez, P., Inkelas, K. K., Rowan-Kenyon, H. T., \& Longerbeam, S. D. (2007). Examining sense of belonging among firstyear undergraduates from different racial/ethnic groups. Journal of College Student Development, 48(5), 525-542.

Laird, T. F. N. (2005). College students' experiences with diversity and their effects on academic self-confidence, social agency, and disposition toward critical thinking. Research in Higher Education, 46(4), 365-387.

Lombardi, M. M. (2007). Authentic learning for the 21st century: An overview. Educause learning initiative, 1(2007), 1-12

Manning, M. L., \& Saddlemire, R. (1996). Developing a sense of community in secondary schools. NASSp Bulletin, 80(584), 41-48.

Martin-Hansen, L. (2018). Examining ways to meaningfully support students in STEM. International Journal of STEM Education, 5(1), 53.

Maton, K. I. Beason, T. S, Godsay, S, Sto. Domingo, M. R, Bailey, T C, Sun, S, \& Hrabowski III, F. A. (2016). Outcomes and processes in the Meyerhoff scholars program: STEM PhD completion, sense of community, perceived program benefit, science identity, and research self-efficacy. CBE-Life Sciences Education, 15(3), ar48

McClain, O. L. (2014). Negotiating identity: A look at the educational experiences of black undergraduates in STEM disciplines. Peabody Journal of Education, 89(3), 380-392.

McIntosh, P. (1988). White privilege: Unpacking the invisible knapsack.

Mraz-Craig, J. A., Daniel, K. L., Bucklin, C. J., Mishra, C., Ali, L., \& Clase, K. L. (2018). Student identities in authentic course-based undergraduate research experience. Journal of College Science Teaching, 48(1).

O'Keeffe, P. (2013). A sense of belonging: Improving student retention. College Student Journal, 47(4), 605-613.

Ong, M., Smith, J. M., \& Ko, L. T. (2018). Counterspaces for women of color in STEM higher education: Marginal and central spaces for persistence and success. Journal of Research in Science Teaching, 55(2), 206-245.

Perez, T., Cromley, J. G., \& Kaplan, A. (2014). The role of identity development, values, and costs in college STEM retention. Journal of educational psychology, 106(1), 315.

Puritty, C., Strickland, L. R., Alia, E., Blonder, B., Klein, E., Kohl, M. T., ... Gerber, L. R. (2017). Without inclusion, diversity initiatives may not be enough. Science, 357(6356), 1101-1102

Rainey, K., Dancy, M., Mickelson, R., Stearns, E., \& Moller, S. (2018). Race and gender differences in how sense of belonging influences decisions to major in STEM. International Journal of STEM Education, 5(1), 10.

Ramsey, L. R., Betx, D. E., \& Sekaquaptewa, D. (2013). The effects of an academic environment intervention on science identification among women in STEM. Social Psychology Education, 16, 377-397.

Reeves, T. C., \& Reeves, P. M. (1997). Effective dimensions of interactive learning on the World Wide Web. Web-based instruction, 59-66.

Salazar, M. R., Lant, T. K., Fiore, S. M., \& Salas, E. (2012). Facilitating innovation in diverse science teams through integrative capacity. Small Group Research, 43(5), 527-558

Simpson, A, \& Bouhafa, Y. (2020). Youths' and adults' identity in STEM: A systematic literature review. Journal for STEM Education Research, 1-28. 
Smith, W., Butcher, E., Litvin, S. W., \& Frash, R. (2015). Incorporating an instructional scaffolding approach into the classroom: Teaching for authentic learning in hospitality and tourism education. Journal of Teaching in Travel \& Tourism, 15(3), 264-277.

Stout, J. G., Dasgupta, N., Hunsinger, M., \& McManus, M. A. (2011). STEMing the tide: using ingroup experts to inoculate women's self-concept in science, technology, engineering, and mathematics (STEM). Journal of personality and social psychology, 100(2), 255.

Strayhorn, T. L. (2012). College students'sense of belonging: A key to educational success for all students. Routledge.

Tonso, K. L. (1999). Engineering gender--gendering engineering: A cultural model for belonging. Journal of Women and Minorities in Science and Engineering, 5, 365-405.

Torres, W. J., Saterbak, A., \& Beier, M. E. (2016). Long-term impact of an elective, first-year engineering design course. In ASEE Annual Conference \& Exposition: Jazzed about Engineering Education.

Wallace, D. E., \& Bodzin, A. M. (2017). Developing scientific citizenship identity using mobile learning and authentic practice. Electronic Journal of Science Education, 21(6), 46-71.

Walton, G. M., \& Cohen, G. L. (2011). A brief social-belonging intervention improves academic and health outcomes of minority students. Science, 337(6023), 1447-1451.

Zuniga, X., Williams, E. A., \& Berger, J. B. (2005). Action-oriented democratic outcomes: The impact of student involvement with campus diversity. Journal of College Student Development, 46(6), 660-678.

\section{Publisher's Note}

Springer Nature remains neutral with regard to jurisdictional claims in published maps and institutional affiliations.

\section{Submit your manuscript to a SpringerOpen ${ }^{\circ}$ journal and benefit from:}

- Convenient online submission

- Rigorous peer review

- Open access: articles freely available online

High visibility within the field

- Retaining the copyright to your article

Submit your next manuscript at $\boldsymbol{\nabla}$ springeropen.com 